\title{
Reproduction of two loricariid species in a confined river and implications for environmental impacts of dams
}

\author{
Lucas De Fries ${ }^{1}$, Gilberto da Rosa ${ }^{1}$, José Pezzi da Silva², Fábio Silveira Vilella ${ }^{3}$ and \\ Fernando Gertum Becker ${ }^{1}$
}

Fish reproduction in floodplain rivers is often linked to flow regime and with the inundation of floodplain habitats. However, in confined rivers, where floodplains are absent, the relation between reproduction and flow can in comparison be expected to be distinct. In this study, we describe the reproductive life-history of Hemiancistrus fuliginosus and Hypostomus isbrueckeri in a confined river and discuss its differences relative to floodplain loricariids and also the implications for effects of dam construction and flow regulation. We found the reproductive peak of both species occurred during lowering waters, just after maximum river flow, in contrast to floodplain species that tend to spawn during rising waters. The studied species presented attributes of equilibrium life-history strategy, which are related to predictable river flow variation. Because both species spawned during low river flow, which is historically predictable in summer, we suggest that their reproduction may be severely disrupted, depending on how flow regime is affected by dam operation. These results have implications for assessing and mitigating the impacts of river damming on fish populations in confined rivers, and we point to ecologically driven flow management and conservation of free-flowing rivers as mitigation and conservation alternatives.

Keywords: Biodiversity, Environment, Flow regulation, Hydropower, Reservoirs.

A reprodução de peixes em rios com planície de inundação está associada ao regime de vazão e sua interação com os hábitats laterais. Entretanto, em rios confinados, sem planícies de inundação, pode-se esperar que a relação entre reprodução e vazão seja comparativamente distinta. Neste estudo, descrevemos as características reprodutivas da história de vida de Hemiancistrus fuliginosus e Hypostomus isbrueckeri em um rio confinado, discutimos as diferenças em relação à reprodução de loricarídeos em planícies de inundação e também as implicações para o efeito de barragens e manejo da vazão de rios. O pico reprodutivo de ambas as espécies ocorreu durante o período de baixa vazão, logo após o período de máxima vazão, contrastando com o padrão observado na reprodução de espécies em planícies de inundação, que ocorre principalmente no período de incremento de vazão. As duas espécies apresentaram história de vida com estratégia de equilíbrio. Pelo fato de ambas espécies desovarem durante a baixa vazão do rio, cuja ocorrência no verão é historicamente previsível, sugerimos que seus padrões de desova podem ser severamente alterados, dependendo de como o regime de vazão for afetado pela operação da barragem. Esses resultados têm implicações para avaliação e manejo de impactos ambientais de barragens em rios confinados, sendo que o manejo ecológico de vazão e a conservação de rios livres de barragens como alternativas de mitigação e conservação, respectivamente.

Palavras-chave: Biodiversidade, Hidrelétricas, Manejo de vazão, Meio ambiente, Reservatórios.

\section{Introduction}

Gonadal development, timing and duration of spawning, and recruitment success of fish can be strongly affected by endogenous and exogenous factors (Bye, 1984). In high latitudes, seasonality in temperature and day length are important abiotic factors controlling reproduction, while in low latitudes, where those factors are relatively invariable, rainfall and floods strongly influence fish reproductive events (Lowe-
McConnell, 1999; Winemiller et al., 2008). Most fish species in tropical streams and rivers spawn just before or just after the onset of flooding (Winemiller et al., 2008; see examples in Paugy, 2002; Rutaisire, Booth, 2005; Bailly et al., 2008) because survival, growth and recruitment of the new cohort occurs in floodplain habitats that become available when river water level rises. Many studies on reproduction, particularly in the neotropics, have largely focused on lowland rivers with floodplains (e.g., Kramer, 1978; Winemiller, 1989;

${ }^{1}$ Departamento de Ecologia, Universidade Federal do Rio Grande do Sul (UFRGS). Av. Bento Gonçalves, 9500, Setor 4, Prédio 43422, CP 15007, 91501-970 Porto Alegre, RS, Brazil. (LDF) lucas.defries@yahoo.com.br, Dhttp://orcid.org/0000-0001-8361-2608 (corresponding author), (GR) gilberto.rosa@ufrgs.br, (FGB) fgbecker@ufrgs.br

${ }^{2}$ JPSBIO Consultoria Ambiental, Estrada Francisca de Oliveira Vieira, 796, 91780-050 Porto Alegre, RS, Brazil. josefpezzi@gmail.com ${ }^{3}$ Simbiota Consultoria Ambiental, Rua Emiliano de Macedo, 1425, 95800-000 Venâncio Aires, RS, Brazil. fabio@simbiota.com.br 
Suzuki et al., 2000, 2004; Agostinho et al., 2004; Andrade, Braga, 2005). Fish reproduction in confined rivers, which are entrenched in narrow valleys with no typical floodplain, however, is much less documented (e.g., Hermes-Silva et al., 2009; Correa et al., 2011; Lopes et al., 2014).

In confined rivers, the advantage of producing offspring in time to benefit from the expanded and productive flooded habitats (Winemiller et al., 2008) is less evident because flooded habitats are much smaller in area and less persistent compared to large floodplain rivers. In confined rivers, growth and refuge habitats for fish offspring are probably located in pools or at tributary confluences (Reynalte-Tataje et al., 2008, 2012; Hermes-Silva et al., 2009; Ávila-Simas et al., 2014). Thus, it is plausible to expect that in confined rivers relations between abiotic factors and fish reproduction will differ from those observed in floodplain rivers, particularly in subtropical latitudes where temperature and daylight are seasonally variable.

Knowledge about reproductive biology of fishes inhabiting confined rivers is particularly important in Brazil, because the physical characteristics of confined channels are usually favorable for damming and hydroelectric power generation (Reynalte-Tataje et al., 2012). In fact, there are more than 700 large dams ( $>15$ meters high) in large rivers of Brazil (Agostinho et al., 2008). This continuous and widespread process of environmental change threatens the spawning of habitats and recruitment of many fish species. Correctly predicting impacts on fish species, and eventually designing adequate conservation plans and management actions, depends on basic life-history information (Agostinho et al., 2007, 2008).
In this study, we have two objectives. The first one is to provide a description of fundamental reproductive characteristics of two armored catfish species (Hemiancistrus fuliginosus Cardoso, Malabarba, 1999 and Hypostomus isbruecke$r i$ Reis, Weber, Malabarba, 1990; Loricariidae) in a confined river just before the closing of a hydroelectric reservoir. The second is to investigate how abiotic factors (flow, temperature, day-length and rainfall) relate to reproduction in a subtropical confined river, under the hypothesis that these relations should be different from those known for floodplain river species.

\section{Material and Methods}

This study was carried out in the Passo Fundo River and its main tributary, the Erechim river, in Southern Brazil. The Passo Fundo River is a major tributary of the Uruguay river, which joins the Paraná river to form the La Plata estuary. It is a confined river with no clear floodplain, flowing along a basaltic plateau, in elevations from $c a 750 \mathrm{~m}$ to $250 \mathrm{~m}$ above sea level (drainage area $=4077 \mathrm{~km}^{2}$; length $=247 \mathrm{~km}$ ). The upper course of the Passo Fundo River was dammed for hydropower production in 1971 upstream from the confluence with the Erechim River (UHE Passo Fundo hydropower

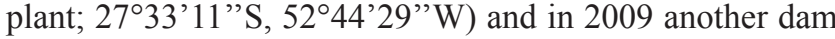
was built downstream of the confluence with the Erechim

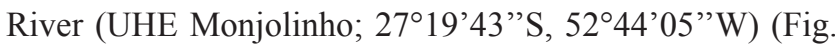
1). River discharge is seasonally variable and predictable, with two typical high flow periods in the late fall and in

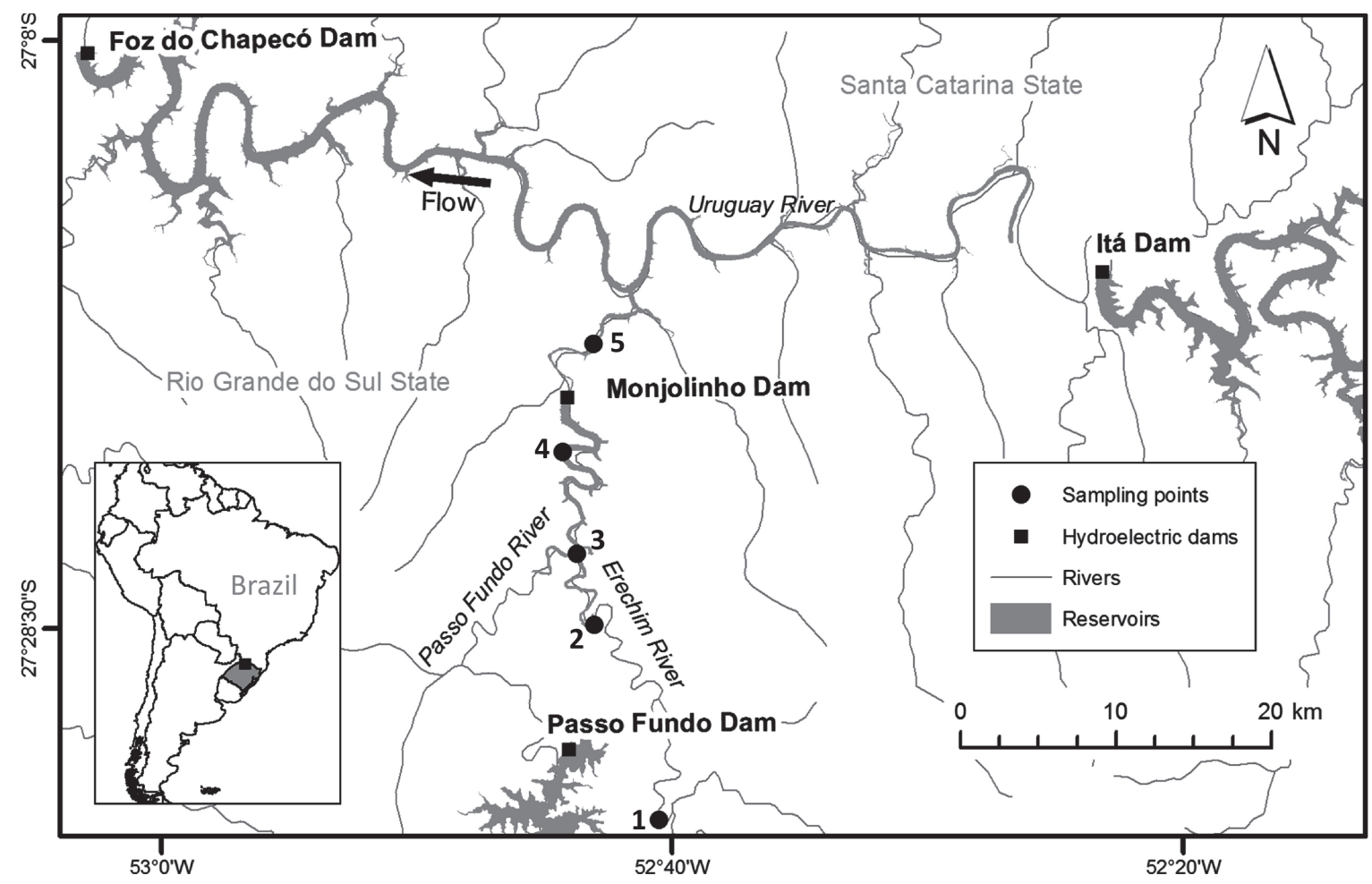

Fig. 1. Geographical situation of the study area and sampling points. Note that fish samples for this study were taken before river damming by the UHE Monjolinho. 
spring, and a lower flow in summer. Climate in the region is humid temperate (Cfa, Köppen classification), with mean annual temperature of $20^{\circ} \mathrm{C}$ and annual rainfall of $2000 \mathrm{~mm}$. Summer temperature (January-March) can reach $38^{\circ} \mathrm{C}$ and negative temperatures may occur in winter. In contrast to tropical parts of South America, there is no clear dry season, although rainfall is higher in fall and spring (Fig. 2).

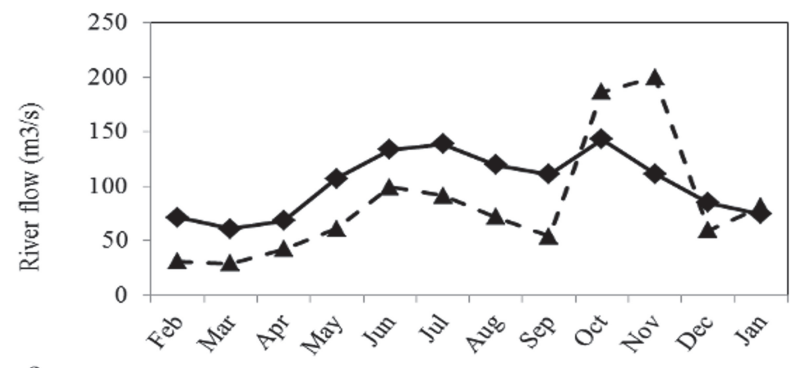

a $\longrightarrow$ Flow $1969-2006 \quad$ Flow 2008-9
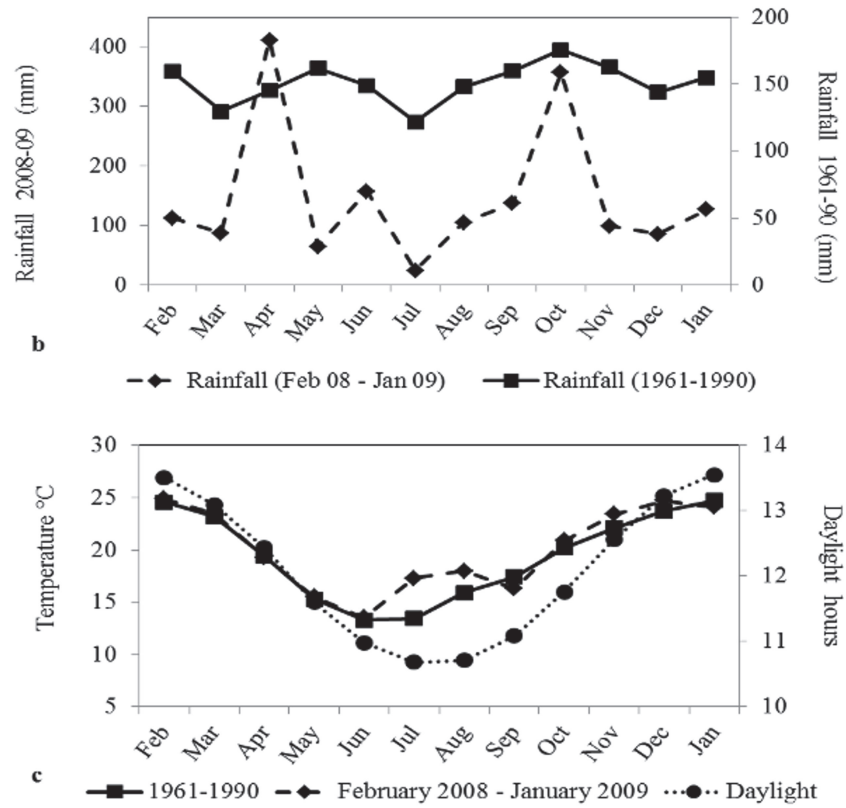

Fig. 2. Historical and observed variation of abiotic factors in the Passo Fundo river basin. a. river flow; b. rainfall; c. air temperature and daylight hours.

We sampled Hem. fuliginosus and Hyp. isbrueckeri approximately every two months, with eight samples encompassing a 12 month period, between February 2008 and January 2009. We placed gillnets in two sites (P1 and P2) at the Erechim River and in three sites (P3, P4 and P5) at the Passo Fundo River (Fig. 1). Erechim River is the main tributary of the Passo Fundo River, and the five sampling points encompassed a $168 \mathrm{~km}$-long stretch of free-flowing confined river upstream from the confluence with Uruguay river.

Our samples were taken before UHE Monjolinho was built, in May 2009. In each sampling site we used one 100-m gillnet set (mesh-sizes: $12 \mathrm{~mm}, 20 \mathrm{~mm}, 30 \mathrm{~mm}, 40 \mathrm{~mm}$ e 50 $\mathrm{mm}$, bar measure between knots), which was set in mid-afternoon and collected in the next morning ( $c a .12$ hours in water). The sampled sites can be described as channels with mainly rocky substrate and occasional sandy patches; water flow is heterogeneous (fast flowing waters and low flowing waters along the same stretch) and riparian vegetation integrity is relatively good. All collected specimens were fixed in $10 \%$ formalin. Voucher specimens for Hem. fuliginosus and Hyp. isbrueckeri were deposited in the Department of Zoology of Universidade Federal do Rio Grande do Sul (UFRGS 11396 and UFRGS 22553, respectively).

From each specimen, we measured total length (to the nearest $\mathrm{mm}$ ) and total weight (g). Gonads were removed, weighted $(0.01 \mathrm{~g})$ and macroscopically inspected for maturity stage. We initially applied a classification with five gonadal development stages (immature, maturing, mature, spawning, spent), but macroscopical distinction of maturing, spawning and spent ovaries was difficult because specimens were initially stored in formalin. We then reallocated gonads to only three categories: immature, mature, and not mature. The $m a-$ ture category included females in early spawning stages (i.e, macroscopical characteristics of both mature and spawning gonads). Oocytes from mature ovaries were counted and measured under stereomicroscope, and these data were used to describe fecundity and oocyte development type.

Gonadosomatic index values (GSI) was calculated as $\mathrm{GSI}=\left(\mathrm{W}_{\mathrm{g}} \mathrm{W}_{\mathrm{t}}^{-1}\right)^{*} 100$, where $\mathrm{W}_{\mathrm{g}}$ is the gonad weight and $\mathrm{W}_{\mathrm{t}}$ is the total weight (Vazzoler, 1996). Condition factor (K) (Le Cren, 1951) was estimated as $\mathrm{K}=\mathrm{W}_{\mathrm{c}} \cdot\left(\mathrm{L}_{\mathrm{t}}^{\mathrm{b}}\right)^{-1}$ where $\mathrm{W}_{\mathrm{c}}=$ $\mathrm{W}_{\mathrm{t}}-\mathrm{W}_{\mathrm{g}}$ and $b$ is the coefficient of the length-weight relation $\left(\mathrm{W}_{\mathrm{t}}=\mathrm{a} \cdot \mathrm{L}_{\mathrm{t}}^{\mathrm{b}}\right)$. We analyzed the monthly frequency of mature females and mean gonadosomatic index values for determining the reproductive season. Monthly differences in mean $\mathrm{K}$ and GSI were tested by one-way non-parametrical ANOVA (Kruskall-Wallis test). We pooled individual data from all five sampling sites to calculate the GSI mean, $\mathrm{K}$ mean, and frequency of mature females in a given month.

The reproductive strategy of the studied species was assessed by examining total and relative fecundity, GSI and size of oocytes. Fecundity was defined as the number of oocytes in mature ovaries $(\mathrm{n}=28$, Hem. fuliginosus; $\mathrm{n}=12$, Hyp. isbrueckeri). Relative fecundity was expressed as the number of oocytes. $\mathrm{Wt}^{-1}$ (after testing for linear relationship between number of oocytes and $\mathrm{W}_{\mathrm{t}}$ ). The type of oocyte development was determined by inspecting the pattern of oocyte size frequency distribution (Vazzoler, 1996).

Size at first maturity $\left(\mathrm{L}_{50}\right)$ was defined as the total length where $50 \%$ of all individuals are predicted to be adults (Vazzoler, 1996). For each species, $\mathrm{L}_{50}$ was estimated by logistic regression (Roa et al., 1999), with total length as independent variable and life stage (either adult or non-adult) as dependent variable. Individuals were classified as either adult or non-adult according to the gonadal maturity stage (non-adult $=$ immature gonads; adults $=$ all other gonadal stages).

To investigate the relation between river flow and reproductive timing, we obtained historical data (1969 to 2006) on river flow (discharge, $\mathrm{m}^{3} / \mathrm{s}$ ) from the fluviometric station "Ponte do rio Passo Fundo" (Agência Nacional de Águas; 
code 73480000; drainage area $=3709 \mathrm{~km}^{2}$ ). Flow data for the study period (February 2008 to January 2009) was obtained from the flow monitoring program at the UHE Monjolinho (drainage area $3770 \mathrm{~km}^{2}$ ). Temperature and rainfall data for the nearest meteorological station (Iraí) were provided by the National Meteorological Institute (INMET $-8^{\circ}$ Distrito), including historical rainfall data (1961-1990). For analysis purposes, all variables were averaged over the period one month (mean river flow in month $m$ is the average of daily flow values in that month).

The relation of reproductive period and condition factor with seasonality of abiotic factors was examined by calculating Pearson correlations between mean monthly values of GSI and K (average of individual values over each sampled month) and river flow (2008-9), historical river flow (19611990), rainfall, day length, and mean monthly air temperature. Because reproductive events may be time lagged (e.g., Torres-Mejia, Ramírez-Pinilla, 2008), correlations were also calculated between GSI at month $m$ and values of abiotic factors one month $(m-1)$ or two months $(m-2)$ before. This procedure resulted in 11 pairwise correlation tests for female GSI, therefore we corrected for multiplicity of tests using the false discovery rate (FDR), i.e, we corrected $p$-values to control the proportion of false positives (Benjamini, Hochberg, 1995; Verhoeven et al., 2005; Waite, Campbell, 2006). We also tested the correlation of fish condition with reproduction and abiotic factors.

\section{Results}

A total of 216 Hem. fuliginosus and 312 Hyp. isbruecke$r i$ were captured. The length frequency distribution in the samples suggests that males of both species tend to reach larger sizes than females (Figs. 3a, b). Sex ratio was not significantly different from 1:1 (Figs. 3c, d). There was no significant difference in the length-weight relation for males and females (Tab. 1).

Reproductive characteristics. Mature ovaries of Hem. fuliginosus contained a lower number of oocytes in comparison to Hyp. isbrueckeri, but oocyte diameter was similar for both species (Tab. 2). Relative fecundity was higher in Hyp. isbrueckeri. The number of oocytes presented positive linear relations to total length (Fig. 4), as well as to gonad weight $\left(\mathrm{n} \quad=13.79 \mathrm{Wg}+21.88 ; p<0.01 ; \mathrm{r}^{2}=0.80\right.$ to Hem. fuliginosus and $\mathrm{n}_{\text {oocytes }}=7.03 \mathrm{Wg}+96.38 ; p<0.01$;
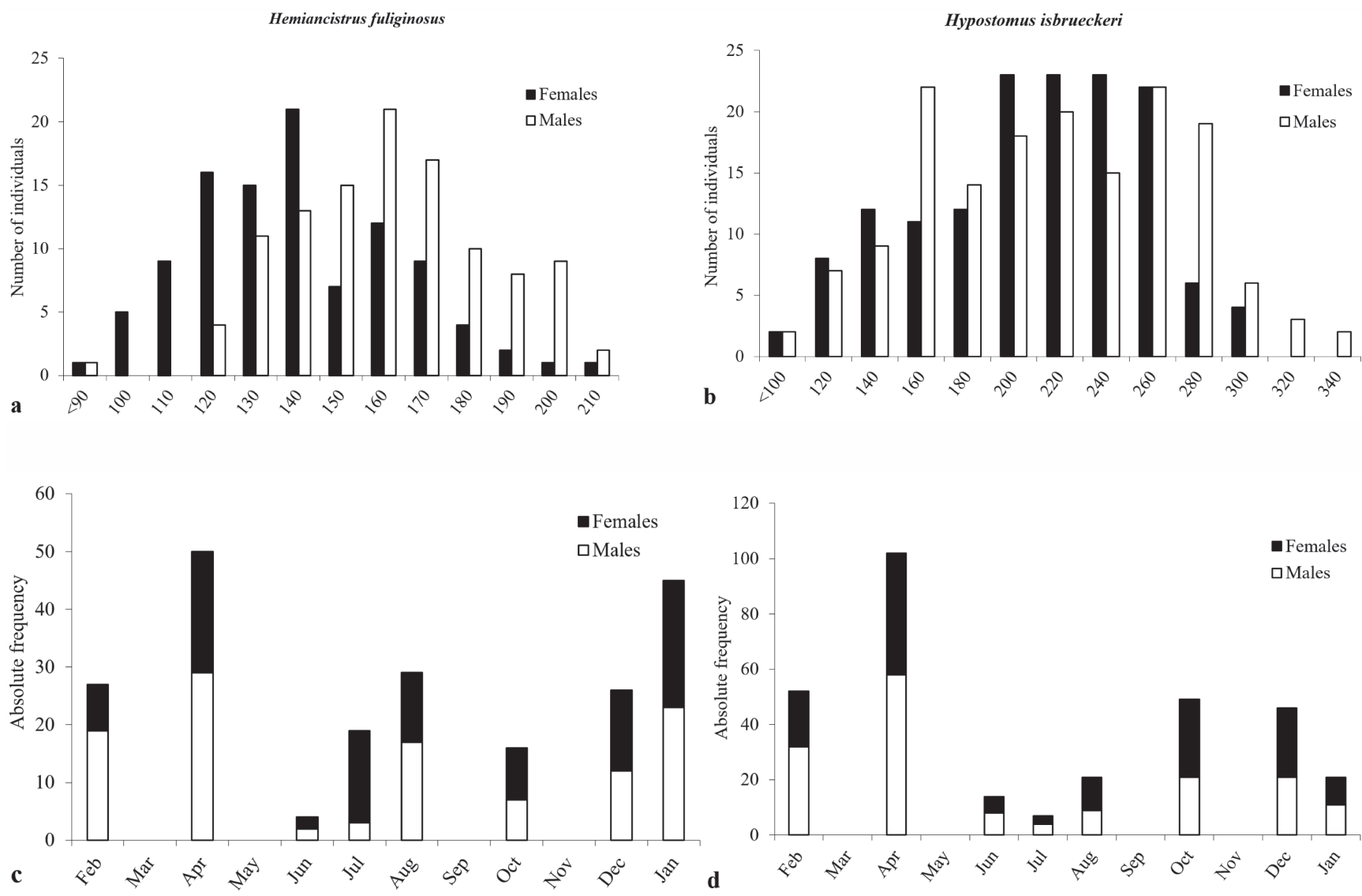

Fig. 3. Total Length $\left(\mathrm{L}_{\mathrm{t}}\right)$ frequency distribution and female/male proportion sampled in the Passo Fundo river basin. a. Hemiancistrus fuliginosus; b. Hypostomus isbrueckeri; c. Hemiancistrus fuliginous; d. Hypostomus isbrueckeri. Proportion of males and females was not significantly different from 1: 1 (Hem. fuliginosus, $\chi^{2}=7.97, \mathrm{df}=7, p<0.34$; Hyp. isbrueckeri, $\left.\chi^{2}=3.47, \mathrm{df}=7, \mathrm{p}<0.34, p<0.84\right)$. 

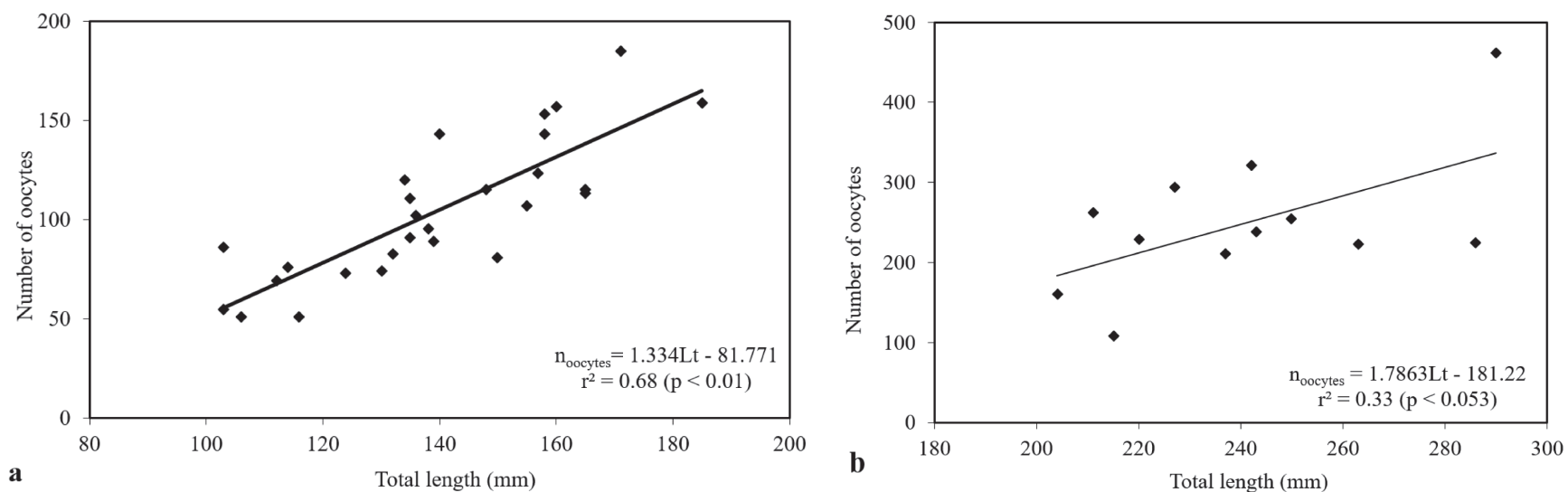

Fig. 4. Relation between number of oocytes and total length. a. Hemiancistrus fuliginosus; b. Hypostomus isbrueckeri.

Tab. 1. Length-weight relations for Hypostomus isbrueckeri and Hemiancistrus fuliginosus. ANCOVA results refer to comparison of parameter $b$ between females and males in each species. $\mathrm{n}=$ number of individuals; $\mathrm{L}_{\mathrm{t}} \min$ and $\mathrm{L}_{\mathrm{t}} \max =\operatorname{minimum}$ and maximum observed Total Length; $a$ and $b=$ parameters of the length-weight relation; $\mathrm{r}^{2}=$ coefficient of determination.

\begin{tabular}{lccccccc}
\hline & Sex & $\mathrm{n}$ & $\mathrm{L}_{\mathrm{t}} \min -\mathrm{L}_{\mathrm{t}} \max (\mathrm{cm})$ & $\mathrm{a}$ & $\mathrm{b}$ & $\mathrm{r}^{2}$ & ANCOVA \\
\hline \multirow{2}{*}{ Hypostomus isbrueckeri } & Female & 167 & $95-297$ & 0.0000136 & 2.985 & 0.982 & $\mathrm{~F}=0.176 ; p=0.67$ \\
& Male & 184 & $94-339$ & 0.0000134 & 2.968 & 0.985 & \\
\multirow{2}{*}{ Hemiancistrus fuliginosus } & Female & 108 & $87-205$ & 0.0000100 & 3.054 & 0.969 & $\mathrm{~F}=1.025 ; p=0.31$ \\
& Male & 122 & $112-208$ & 0.0000180 & 2.950 & 0.968 & \\
\hline
\end{tabular}

Tab. 2. Fecundity and oocyte diameter of Hemiancistrus fuliginosus ( $\mathrm{n}=27$ mature females) and Hypostomus isbrueckeri $(\mathrm{n}=12$ mature females).

\begin{tabular}{lcc}
\hline & Hemiancistrus fuliginosus & Hypostomus isbrueckeri \\
\hline Mean number of oocytes $(\min -\max )$ & $104.4(51-185)$ & $248.7(108-462)$ \\
Relative fecundity $(\mathrm{n}$ oocytes $/ \mathrm{g})$ & 2.53 & 1.47 \\
Oocyte diameter in mature ovaries $(\mathrm{mm})$ & $0.3-6.8$ & $0.2-7$ \\
\hline
\end{tabular}

$\mathrm{r}^{2}=0.57$ to Hyp. isbrueckeri) and total weight just to Hem. fuliginosus $\left(\mathrm{n}{ }_{\text {oocytes }}=1.41 \mathrm{Wt}+41.38 ; p<0.01 ; \mathrm{r}^{2}=0.68\right)$. The two modes in the size frequency distribution of oocytes indicate that oocyte development is group-synchronic with two groups (Fig. 5).

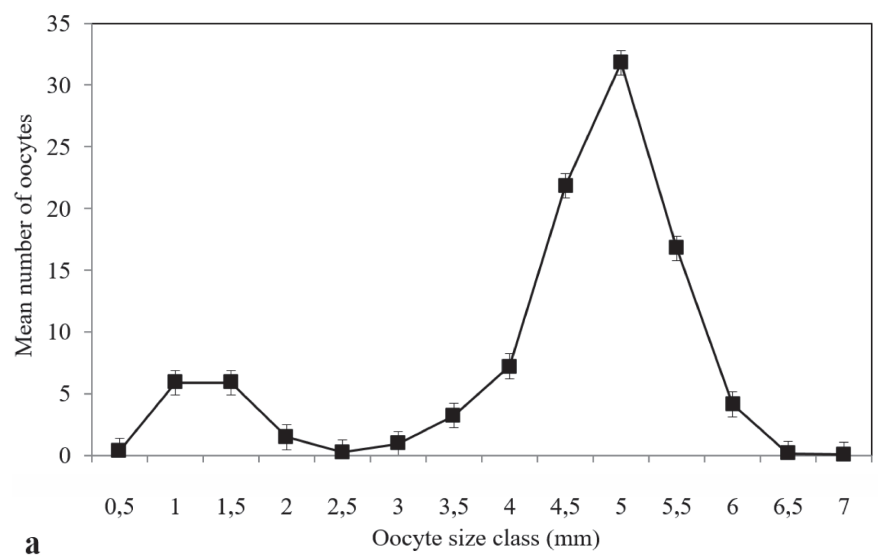

Mature females of both species were observed from October 2008 to January 2009, suggesting that reproductive activity may have initiated in early spring (Fig. 6), however, monthly changes in mean GSI and variation of individual GSI values (Figs. 7a, b) indicate that reproduction

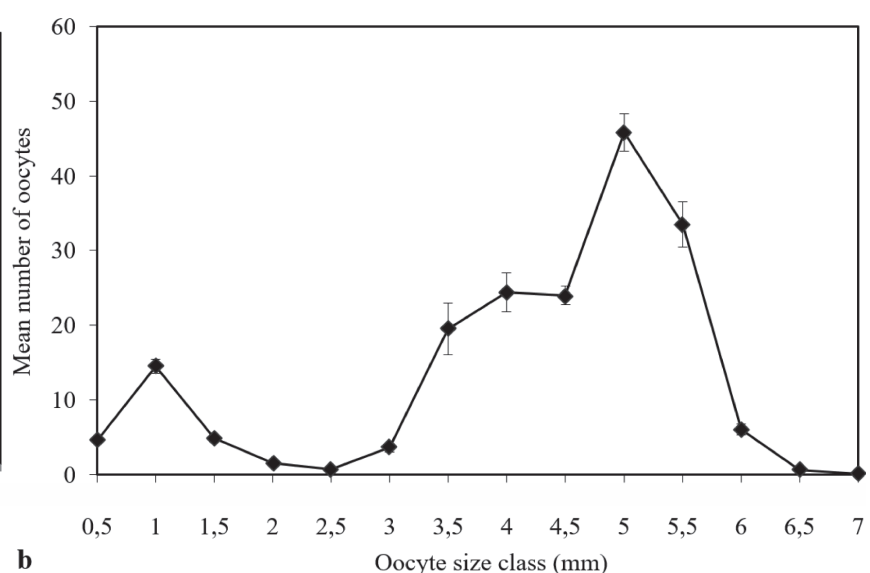

Fig. 5. Mean frequency ( $\pm \mathrm{SE})$ of oocytes per size (diameter) class in mature ovaries. a. Hemiancistrus fuliginosus $(\mathrm{n}=27)$; b. Hypostomus isbrueckeri $(\mathrm{n}=12)$ in the Passo Fundo and Erechim rivers, southern Brazil. 
was concentrated in a two-month period during summer (December and January). Females of Hem. fuliginosus reached maximum gonad development at smaller lengths than Hyp. isbrueckeri (Figs. 8a, b), with most individuals of Hem. fuliginosus probably spawning between January and February and Hyp. isbrueckeri between December and January. Immature females were found all year round, except in late fall (June; Fig. 6). Apparently, there were no mature males

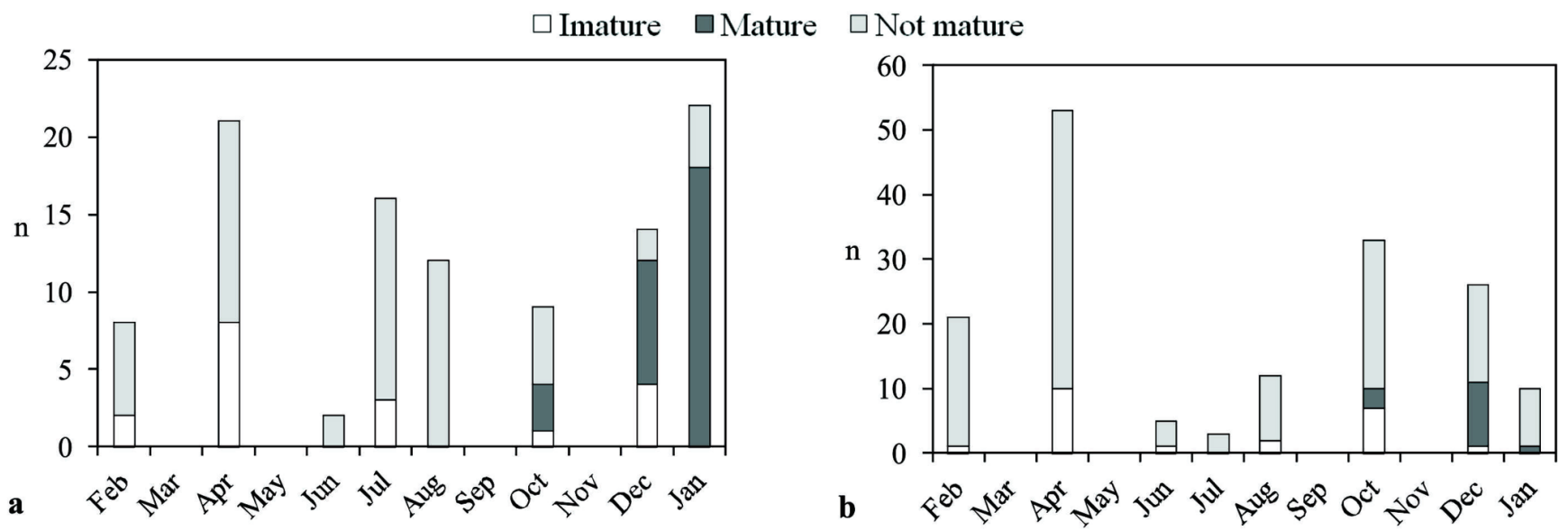

Fig. 6. Frequency of ovarian maturity stages. a. Hemiancistrus fuliginosus; b. Hypostomus isbrueckeri in the Passo Fundo river basin, between February 2008 and January 2009.

Hemiancistrus fuliginosus
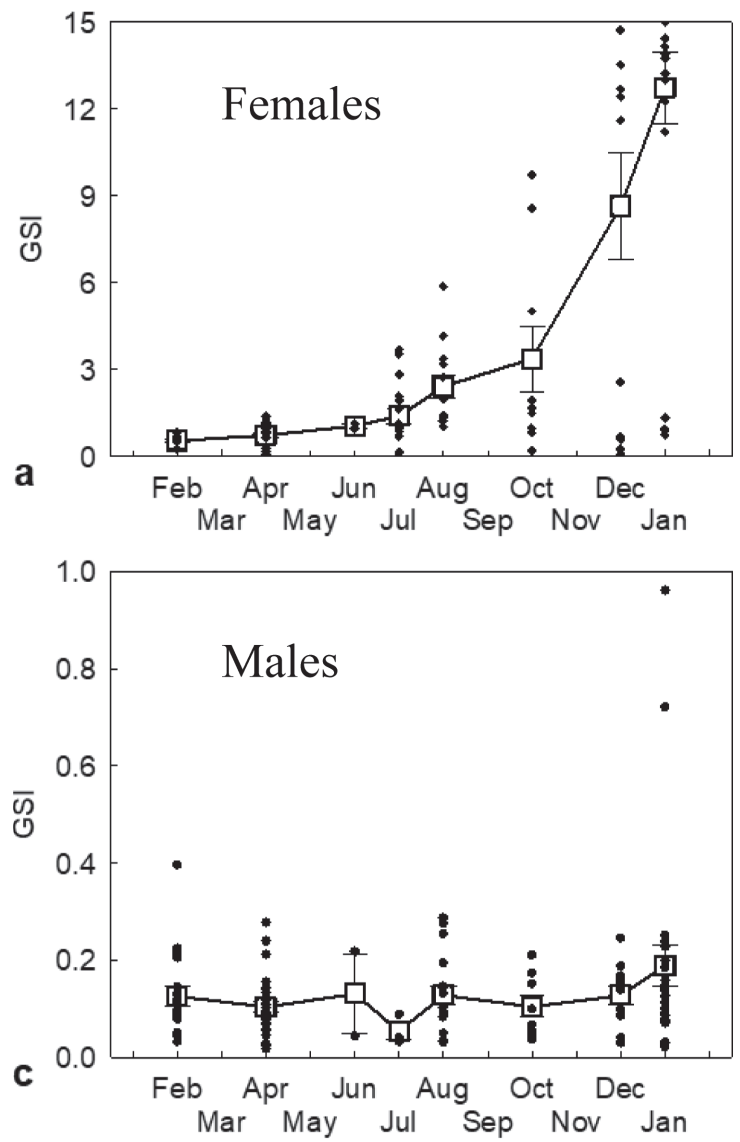

Hypostomus isbrueckeri
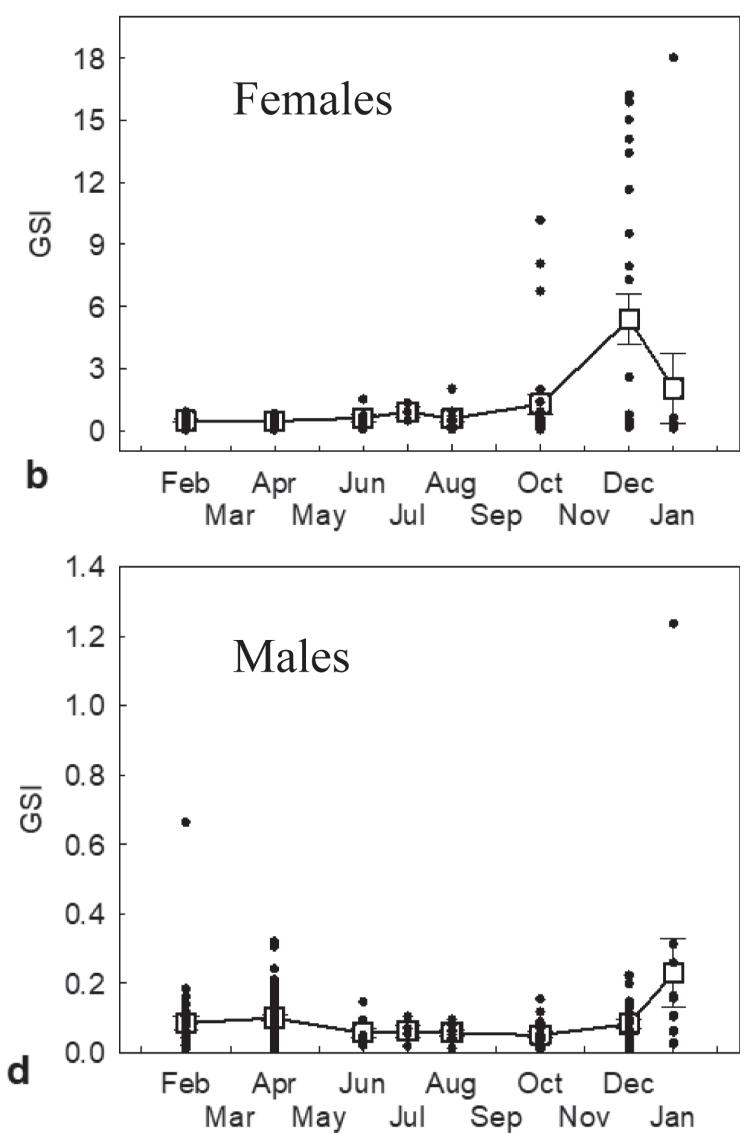

Fig. 7. Monthly changes in mean ( \pm SE) gonadosomatic index (GSI; dots represent individual values) of Hemiancistrus fuliginosus (a. females; c. males) and Hypostomus isbrueckeri (b. females; d. males). Results of the Kruskal-Wallis tests: Hem. fuliginosus females, $\mathrm{H}=47.5, \mathrm{df}=7, p<0.001$; males, $\mathrm{H}=6.9$, $\mathrm{df}=7, p<0.44$; Hyp. isbrueckeri females, $\mathrm{H}=14.4$, $\mathrm{df}=7$, $p<0.045$, males $\mathrm{H}=20.4, \mathrm{df}=7, p<0.005$. 


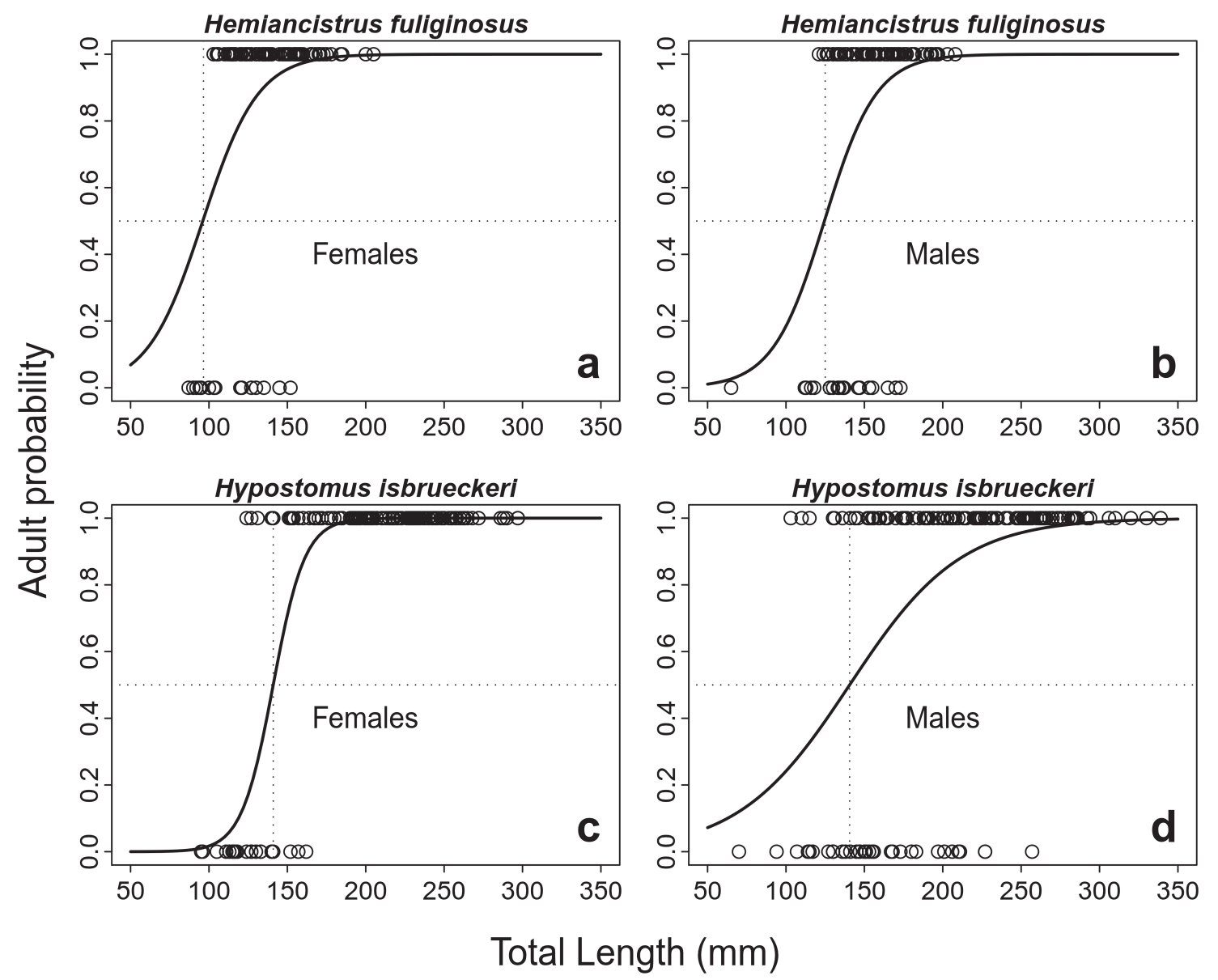

Fig. 8. Logistic regressions for estimating size at first maturity Hemiancistrus fuliginosus and Hypostomus isbrueckeri in the Passo Fundo and Erechim rivers, southern Brazil.

of either species in our samples, but this could have been a bias resulting from our procedure for maturity stage classification (only macroscopical inspection). Length at first maturity was $96.5 \mathrm{~mm}$ (females) and $125 \mathrm{~mm}$ (males) for Hem. fuliginosus, and $141 \mathrm{~mm}$ (females) and $140.7 \mathrm{~mm}$ (males) for Hyp. isbrueckeri (Fig. 8).

Reproduction and Abiotic factors. The GSI of both species was significantly correlated only to time-lagged river flow (Tab. 3). For Hem. fuliginosus females, mean GSI was correlated with river flow after a two-month delay, while for Hyp. isbrueckeri females there was one-month delay (Tab. 3, Fig. 9 ). No other environmental variable was correlated to GSI variation during the study period, although the increase in female GSI generally coincided with increasing temperature and daylight hours. Therefore, for both species, the peak gonadal maturity and the subsequent spawning (steep decrease in GSI, Fig. 7) seem to have occurred during low river flow period in summer, after the spring high flow period (which is a historically consistent flow pattern, Fig. 9). Condition factor varied significantly along the sampling period (except for male Hyp. isbrueckeri) (Fig. 10), but it was not related to the gonadal cycle or to abiotic variables (Pearson correlations were not significant after correction for FDR).

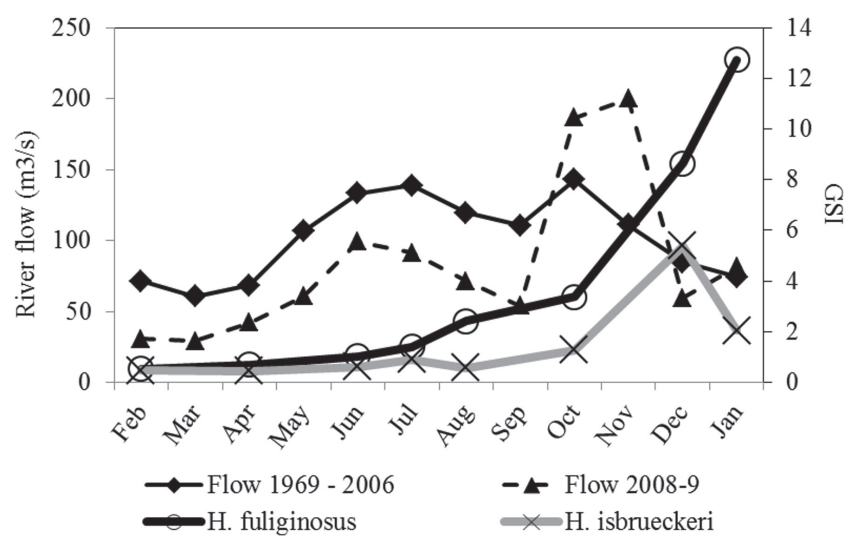

Fig. 9. Observed variation of river flow and mean gonadosomatic index (GSI) of Hemiancistrus fuliginosus (females) and Hypostomus isbrueckeri (females) in the Passo Fundo and Erechim rivers.

\section{Discussion}

The reproductive characteristics, population size and sex structure of Hem. fuliginosus and Hyp. isbrueckeri indicate that these species tend toward an equilibrium strategy (total spawning, balanced sex ratio, low fecundity and large oo- 
Hemiancistrus fuliginosus
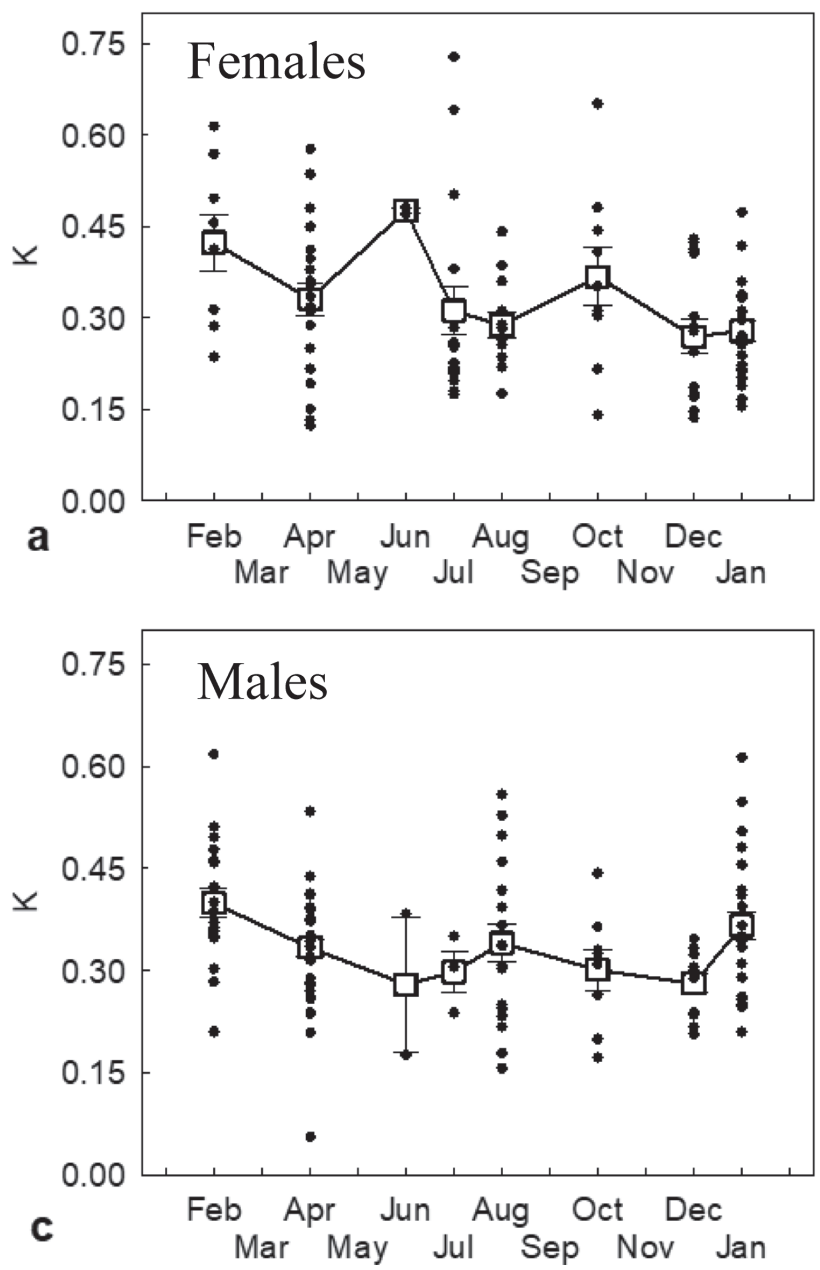

Hypostomus isbrueckeri
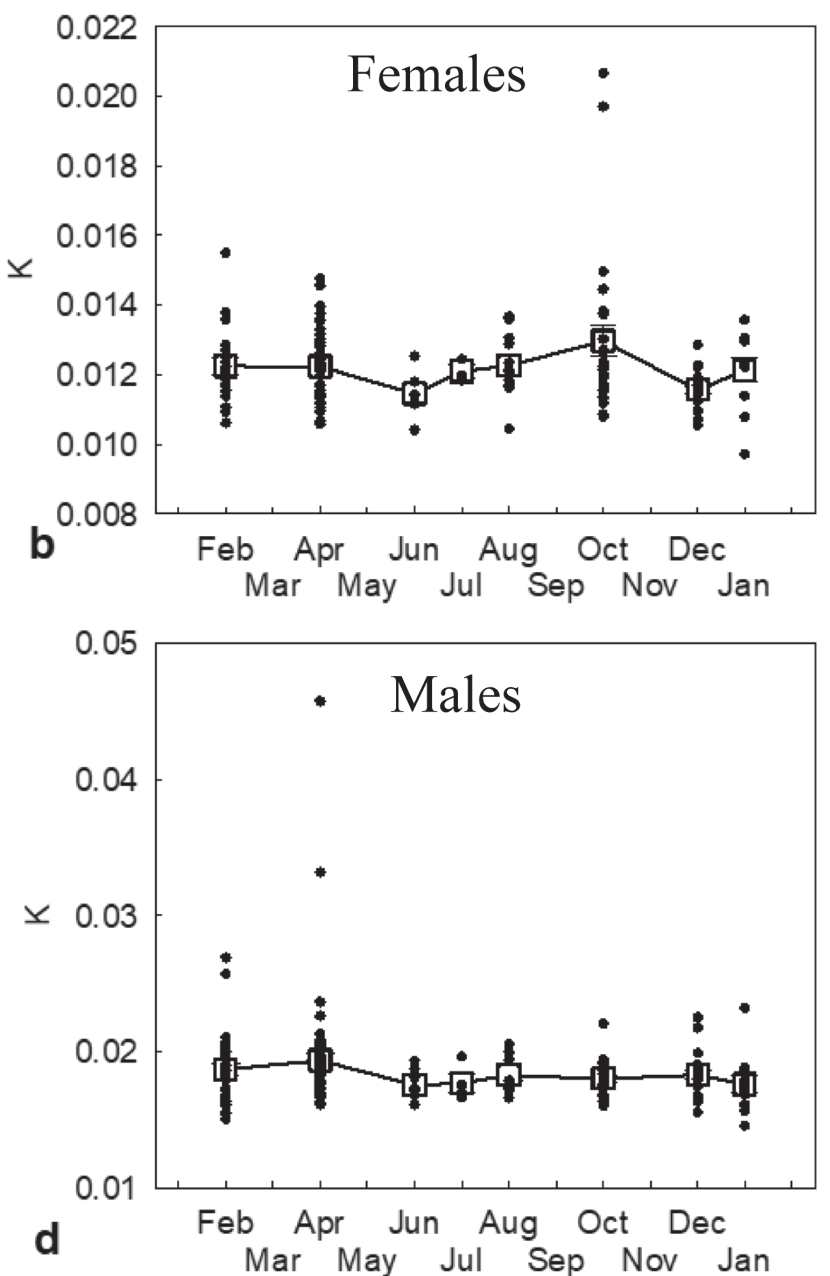

Fig. 10. Monthly changes in mean ( $\pm \mathrm{SE}$ ) condition factor (K; dots represent individual values) of Hemiancistrus fuliginosus (a. females; c. males) and Hypostomus isbrueckeri (b. females; d. males). Condition factor (K) varied significantly for Hem. fuliginosus (Kruskal-Wallis test; females $\mathrm{H}=15.14$, $\mathrm{df}=7 ; p=0,034$; males $\mathrm{H}=16.52, \mathrm{gl}=7 ; p=0,021$ ); and female Hyp. isbrueckeri $(\mathrm{H}=16.34, \mathrm{df}=7, p=0,022)$, but not for male Hyp. isbrueckeri $(\mathrm{H}=10.65, \mathrm{df}=7, p=0,155)$.

cytes; see Winemiller (1989) and Winemiller, Rose (1992). This strategy has been commonly attributed to armored-catfishes (Winemiller et al., 2008; Gomes et al., 2015), however, loricariids can also exhibit tactics of non-equilibrium strategists, such as multiple spawning (Mazzoni, Caramaschi, 1997a), unbalanced sex ratio (Goulart, Verani, 1992) and high fecundity (for instance, maximum fecundity $>$ 2.800, see Suzuki et al., 2000).

The reproductive period of Hem. fuliginosus (October to February) and Hyp. isbrueckeri (October to January) is similar to that of other loricariids from tropical latitudes, although armored catfishes encompass a wide diversity of forms and behaviors (Burgess, 1989; Agostinho et al., 1995; Suzuki et al., 2000). Present knowledge about loricariid life-history indicates that reproduction takes place in spring and summer (Agostinho et al.,1987, 1991; Mazzoni, Caramaschi, 1995, 1997a, 1997b; Ramos, Konrad, 1998, 1999; Hirschmann et al., 2011; Gomes et al., 2015), as is also the case for many other Neotropical groups (Lampert et al., 2004; Dala-Corte, Azevedo, 2010). However, in contrast to species from tropical latitudes and floodplain rivers, we observed that GSI values of Hem. fuliginosus and Hyp. isbrueckeri females were strongly correlated to flow in the months preceding spawning $(\mathrm{r} \geq 0.87$; two-month lag for Hem. fuliginosus and one-month lag for Hyp. isbrueckeri); and a weaker positive relation with daylight and temperature $(0.5$ $<\mathrm{r}<0.7)$. Other studies in upper Uruguay River suggest that temperature increase is the trigger to fish reproductive activity (Hermes-Silva et al., 2009; Correa et al., 2011; Lopes et al., 2014), but we observed that GSI variation was highly related to two-month previous river flow, while temperature and daylight were only mildly related to GSI variation. Fish eggs and larvae studies have revealed that fish reproduction is highly seasonal in the Upper Uruguay River, being related to temperature and water flow (Correa et al., 2011). Flow regime has a strong relationship with fish life history (Te- 
Tab. 3. Pearson correlations (r) between monthly mean of gonadosomatic index $(\mathrm{GSI})$ and monthly values $(\mathrm{n}=8)$ of environmental variables in the Passo Fundo river (Brazil). Significance of the correlations was determined using the false discovery rate (FDR) procedure. Significant correlations $(p \leq 0.05)$ are in bold and underlined. Lagged variables are indicated by $i-1$ and $i-2$ for one and two-month shifts respectively (see text).

\begin{tabular}{lccccc}
\hline & \multicolumn{2}{c}{ H. fuliginosus } & & \multicolumn{2}{c}{ H. isbrueckeri } \\
\cline { 2 - 3 } \cline { 6 - 7 } & GSI $_{\text {Females }}$ & GSI $_{\text {Males }}$ & & GSI $_{\text {Females }}$ & GSI $_{\text {Males }}$ \\
\hline Daylight hours & 0.69 & 0.55 & & 0.62 & 0.55 \\
Flow 1969-1990 & -0.34 & -0.51 & & -0.23 & -0.61 \\
Flow 2008 & 0.05 & -0.16 & & -0.05 & -0.24 \\
Total rainfall $(\mathrm{mm})$ & -0.23 & -0.01 & & -0.27 & -0.06 \\
Temperature $\left({ }^{\circ} \mathrm{C}\right)$ & 0.57 & 0.39 & & 0.53 & 0.49 \\
Flow 2008 $(-1 \mathrm{month})$ & 0.41 & -0.10 & & $\underline{\mathbf{0 . 8 7}}$ & -0.15 \\
Total rainfall $(\mathrm{mm})(-1$ month) & -0.10 & -0.54 & & 0.06 & -0.09 \\
Temperature air $\left({ }^{\circ} \mathrm{C}\right)(-1$ month) & 0.48 & 0.62 & & 0.36 & 0.65 \\
Flow 2008 $(-2 \mathrm{months})$ & $\underline{\mathbf{0 . 9 5}}$ & 0.63 & & 0.76 & 0.65 \\
Total rainfall $(\mathrm{mm})(-2$ months) & 0.05 & 0.21 & & 0.44 & -0.26 \\
Temperature air $\left({ }^{\circ} \mathrm{C}\right)(-2$ months $)$ & 0.19 & 0.43 & 0.10 & 0.53 \\
\hline
\end{tabular}

desco, Hugheny, 2006; Olden et al., 2006; Tedesco et al., 2008), especially with predictability and variability of river flow (Olden, Kennard, 2010). We then suggest that temperature and day-light are probably related to the acceleration of gonadal development, but spawning (as measured by steep decrease in GSI) is probably related to seasonally predictable decreases in river flow.

We also found that peak reproduction of Hem. fuliginosus and Hyp. isbrueckeri was delayed in relation to river flow, occurring in summer, just after the decrease of peak river flow, differing from the reproductive pattern of floodplain species, which tend to reproduce during rising waters, preceding flood peaks (Agostinho et al., 1991; Paugy, 2002; Agostinho et al., 2004; Suzuki et al., 2004; Rutaisire, Booth, 2005; Andrade, Braga, 2005; Bailly et al., 2008). In confined rivers, discharge increase may result in unfavorable conditions for reproduction (for example, higher mortality or lower recruitment due to physical removal of eggs, larvae and spawning substrate), thus, reproducing during low flow would represent a more favorable condition (Pusey et al., 2001). Humphries et al. (1999) proposed that in rivers with relatively unpredictable flood dynamics or where flood does not coincide with adequate temperatures, recruitment should occur during low-flow (Low Flow Recruitment hypothesis, LFR). According to Humphries et al. (1999), periods of low flow during summer are more predictable from year to year. In our study, the historic flow 1969-2006 and flow 2008-9 showed a predictable low flow pattern during summer in the Passo Fundo River. In situations where LFR is plausible, fish reproduction should coincide with predictable low flows, when temperatures are warm and food resources are more concentrated (Lytle, Poff, 2004; Zeug, Winemiller, 2007).
Additionally, we speculate that suitable physical conditions for oviposition (water depth and velocity) possibly become more available during the recession limb of the hydrograph. Such coincidence between life-history (reproductive) and low river flow in summer may result in higher fitness (Lytle, Poff, 2004). In the upper Uruguay River, ichthyoplankton studies have shown that pool habitat formation during summer - in low flow and high temperature conditions - is relevant for development of loricariid species (Hypostomus spp., Loricariichthys spp. and Rineloricaria spp.), because pool habitats provide both favorable physical habitat conditions and concentration of food resources for larvae growth (Ávila-Simas et al., 2014; Lopes et al., 2014). According to Correa et al. (2011), the particular topography of the upper Uruguay River favors spawning in the rapids, and pools are used as nursery areas for larvae. We thus suggest that, in confined rivers, reproduction of fish - both migratory and non-migratory - has a distinct relation with abiotic factors in comparison to reproduction in floodplain rivers. In confined rivers, because of the absence of floodplain habitats (floodplain lakes, back waters and wetlands), fish reproduction must take place within the river channel, so that mortality of early-life stages is much more dependent on flow variation. In this sense, predictability of flow (particularly of low-flow) and its coincidence with historical river flow patterns, would be key factors for reproductive success and population persistence in the long term (Lytle, Poff, 2004). Under these circumstances, species tending to equilibrium life-history strategies, with reproduction synchronized with low river flow, might be relatively more common than in other environments. Both these later ideas should be tested in the future, by assessing reproduction of other species in a wider taxonomic scope (families, orders) and in comparison to other environments.

Our results have implications for assessing and mitigating the impacts of river damming on fish populations in confined rivers. Because river damming and flow management affect the predictability of low flow in confined rivers, fish reproduction could be severely affected, particularly for species that evolved to cope with natural flow regimes (seen Lytle, Poff, 2004). The fish species studied here presented an equilibrium life history strategy (Winemiller, 1989; Winemiller, Rose, 1992) correlated to a historical pattern of low river flow in summer. Equilibrium strategists are expected to be positively related with predictability of water flow and to be favored in more stable environments (Mims, Olden, 2012, 2013; Gomes et al., 2015). The formation of the UHE Monjolinho reservoir could affect the spawning of Hem. fuliginosus and Hyp. isbrueckeri, which are cumulatively affected by flow regulation by the upstream Passo Fundo Dam, resulting in the disappearance of favorable environments for recruitment of loricariids species and of the hydrological regime associated to the reproductive cycle. Drastic reduction in loricariids after reservoir formation has been previously reported (see Agostinho et al. (1999) for Hypostomus sp. and Hirschmann et al. (2008) for Hemiancistrus punctula- 
tus). Our results thus add support to the need for managing river flow in accordance to the historical patterns under which fish populations evolved. This means not only that seasonal flow patterns should be taken into account in reservoir operation, but also that short-term (few hours) extreme variations in flow should be avoided. Short-term extreme variation in discharge is common in dammed confined rivers as a result of high demand for power generation. Ecologically oriented management of low flow during summer could be a useful strategy for conservation of fish species in dammed confined rivers. Clearly, information about fish life-history and its relation to abiotic factors should be obtained before dam construction and fish monitoring programs demanded by environmental agencies should objectively assess how fish reproduction is affected. Flow management should than be regulated in a multiobjective manner that includes not only power generation, but also fish life-cycles, according to the Natural Flow Paradigm (Poff et al., 1997; Lytlle, Poff, 2004). A complementary conservation strategy would be the preservation of undammed or, at least, unregulated confined free-flowing rivers or river segments.

\section{Acknowledgments}

Camila Fagundes Dias e Francini de Souza provided help in the field and laboratory. Monel (Monjolinho Energética Ltda.) provided financial support for data collection. We are thankful to Sandra M. Hartz and Renato B. Dala-Corte for several suggestions to earlier versions of the manuscript. We also would like to acknowledge the referees for several comments that helped improving the manuscript.

\section{References}

Agostinho AA, Barbieri MC, Barbieri G, Agostinho CS. Biologia reprodutiva de Rhinelepis aspera (Agassiz, 1829) (Teleostei, Loricariidae) no rio Paranapanema. II. Estrutura dos ovários e estádios de maturação. Rev Bras Biol. 1987; 47(3):319-28.

Agostinho AA, Gomes LC, Pelicice FM. Ecologia e manejo de recursos pesqueiros em reservatórios do Brasil. Maringá: Eduem; 2007.

Agostinho AA, Gomes LC, Veríssimo S, Okada EK. Flood regime, dam regulation and fish in the Upper Paraná River: effects on assemblage attributes, reproduction and recruitment. Rev Fish Biol Fish [serial on the Internet]. 2004; 14(1):11-19. Available from: https://doi.org/10.1007/s11160-004-3551-y

Agostinho AA, Hahn NS, Agostinho CS. Ciclo reprodutivo e primeira maturação de fêmeas de Hypostomus commersonii (Valenciennes, 1840) (Siluriformes, Loricariidae) no reservatório Capivari-Cachoeira, PR. Rev Bras Biol. 1991; 51(1):31-37.

Agostinho AA, Matsuura Y, Okada EK, Nakatani K. The catfish, Rhinelepis aspera (Teleostei; Loricariidae) in the Guaíra region of the Paraná river: an example of population estimation from catch-effort and tagging data when emigration and immigration are high. Fish Res [serial on the Internet]. 1995; 23(3-4):333-44. Available from: https://doi.org/10.1016/01657836(94)00347-Y
Agostinho AA, Miranda LE, Bini LM, Gomes LC, Thomaz SM, Suzuki HI. Patterns of colonization in neotropical reservoirs, and prognoses on aging. In: Tundisi JG, Straskraba MS, editors. Theoretical reservoir ecology and its applications. São Carlos: International Institute of Ecology (IEE); 1999. p.227-265.

Agostinho AA, Pelicice FM, Gomes LC. Dams and the fish fauna of the Neotropical region: impacts and management related to diversity and fisheries. Braz J Biol [serial on the Internet]. 2008; 68(4, suppl. 0):1119-32. Available from: http://dx.doi. org/10.1590/S1519-69842008000500019

Andrade PM, Braga FMS. Reproductive seasonality of fishes from a lotic stretch of the Grande river, high Paraná river basin, Brazil. Braz J Biol [serial on the Internet]. 2005; 65(3):387-94. Available from: http://dx.doi.org/10.1590/S1519-69842005000300003

Ávila-Simas S, Reynalte-Tataje DA, Zaniboni-Filho E. Pools and rapids as spawing and nursery areas for fish in a river stretch without floodplains. Neotrop Ichthyol [serial on the Internet]. 2014; 12(3):611-22. Available from: http://dx.doi. org/10.1590/1982-0224-20130116

Bailly D, Agostinho AA, Suzuki HI. Influence of the flood regime on the reproduction of fish species with different reproductive strategies in the Cuiaba river, Upper Pantanal, Brazil. River Res Appl [serial on the Internet]. 2008; 24(9):1218-29. Available from: https://doi.org/10.1002/rra.1147

Benjamini Y, Hochberg Y. Controlling the false discovery rate: a practical and powerful approach to testing. J R Stat Soc Series B Stat Methodol [serial on the Internet]. 1995; 57(1):289-300. Available from: https://www.jstor.org/stable/2346101

Burgess WE. An atlas of freshwater and marine catfishes: a preliminary survey of the Siluriformes. Neptune: TFH publications Inc; 1989.

Bye VJ. The role of environmental factors in the timing of reproductive cycles. In: Potts GW, Wooton RJ, editors. Fish reproduction: strategies and tactics. London: Academic press; 1984. p.187-205.

Cardoso AR, Malabarba LR. Description of three new species of Hemiancistrus Bleeker, 1862 from Southern Brasil (Teleostei: Siluriformes: Loricariidae). Comun Mus Ciênc Pucrs Sér Zool. 1999; 12:141-61.

Correa RN, Hermes-Silva S, Reynalte-Tataje D, Zaniboni-Filho E. Distribution and abundance of fish eggs and larvae in three tributaries of the Upper Uruguay River (Brazil). Environ Biol Fishes [serial on the Internet]. 2011; 91(1):51-61. Available from: https://doi.org/10.1007/s10641-010-9759-x

Dala-Corte RB, Azevedo MA. Biologia reprodutiva de Astyanax henseli (Teleostei, Characidae) do curso superior do rio dos Sinos, RS, Brasil. Iheringia Ser Zool. 2010; 100(3):259-66.

Gomes ID, Araújo FG, Nascimento AA, Sales A. Equilibrium reproductive strategy of the armored catfish Hypostomus auroguttatus (Siluriformes, Loricariidae) in a tropical river in Southeastern Brazil. Environ Biol Fishes [serial on the Internet]. 2015; 98(1):249-60. Available from: https://doi. org/10.1007/s10641-014-0256-5

Goulart E, Verani JR. Proporção sexual, relação peso/comprimento e fator de condição de Hypostomus commersonii Valenciennes, 1840 (Osteichthyes Loricariidae) da represa Capivari-Cachoeira, Paraná, Brasil. Rev Unimar. 1992; 14: 19-33.

Hermes-Silva S, Reynalte-Tataje D, Zaniboni-Filho E. Spatial and temporal distribution of ichthyoplankton in the Upper Uruguay river, Brazil. Braz Arch Biol Technol [serial on the Internet]. 2009; 52(4):933-44. Available from: http://dx.doi.org/10.1590/ S1516-89132009000400017 
Hirschmann A, Fialho CB, Grillo HCZ. Reprodução de Hemiancistrus punctulatus Cardoso \& Malabarba, 1999 (Siluriformes: Loricariidae) no sistema da laguna dos Patos: uma espécie de ambiente lótico frente às alterações provocadas por represamentos. Neotrop Biol Conserv. 2011; 6(3):250-57.

Hirschmann A, Majolo MA, Grillo HCZ. Alterações na ictiocenose do rio Forqueta em função da instalação da Pequena Central Hidrelétrica Salto Forqueta, Putinga, Rio Grande do Sul. Iheringia Ser Zool. 2008; 98(4):481-88.

Humphries P, King AJ, Koehn JD. Fish, flows and flood plains: links between freshwater fishes and their environment in the Murray-Darling River system, Australia. Environ Biol Fishes [serial on the Internet]. 1999; 56(1-2):129-51. Available from: https://doi.org/10.1023/A:1007536009916

Kramer DL. Reproductive seasonality in the fishes of a tropical stream. Ecology [serial on the Internet]. 1978; 59:976-85. Available from: https://doi.org/10.2307/1938549

Lampert VR, Azevedo MA, Fialho CB. Reproductive biology of Bryconamericus iheringii (Ostariophysi: Characidae) from rio Vacacaí, RS, Brasil. Neotrop Ichthyol [serial on the Internet]. 2004; 2(4):209-15. Available from: http://dx.doi.org/10.1590/ S1679-62252004000400003

Le Cren ED. The length-weight relationship and seasonal cycle in gonad weight and condition in the perch (Perca fluviatilis). J Anim Ecol. 1951; 20(2):201-19.

Lopes CA, Garcia V, Reynalte-Tataje DA, Zaniboni-Filho E, Nuñer APO. Temporal distribution of ichthyoplankton in the Forquilha river, upper Uruguay river - Brazil: relation with environmental factors. Acta Sci Biol Sci [serial on the Internet]. 2014; 36(1):59-65. Available from: https://doi.org/10.4025/ actascibiolsci.v36i1.17993

Lowe-McConnell RH. Estudos ecológicos de comunidades de peixes tropicais.Vazzoler AEAM, Agostinho AA, Cunningham PTM, tradutores. São Paulo: Edusp; 1999. (Coleção Base). Original title: Ecological studies in tropical fish communities.

Lytle DA, Poff NL. Adaptation to natural flow regimes. Trends Ecol Evol [serial on the Internet]. 2004; 19(2):94-100. Available from: https://doi.org/10.1016/j.tree.2003.10.002

Mazzoni R, Caramaschi EP. Size structure, sex ratio and onset of sexual maturity of two species of Hypostomus. J Fish Biol [serial on the Internet]. 1995; 47(5):841-49. Available from: https://doi.org/10.1111/j.1095-8649.1995.tb06006.x

Mazzoni R, Caramaschi EP. Spawning season, ovarian development and fecundity of Hypostomus affinis (Osteichthyes, Loricariidae). Rev Bras Biol. 1997a; 57(3):455-62.

Mazzoni R, Caramaschi EP. Observations on the reproductive biology of female Hypostomus luetkeni Lacèpéde 1803. Ecol Freshw Fish [serial on the Internet]. 1997b; 6(1):53-56. Available from: https://doi.org/10.1111/j.1600-0633.1997.tb00143.x

Mims MC, Olden JD. Life history theory predicts fish assemblage response to hydrologic regimes. Ecology [serial on the Internet]. 2012; 93(1):35-45. Available from: https://doi.org/10.1890/110370.1

Mims MC, Olden JD. Fish assemblages respond to altered flow regimes via ecological filtering of life history strategies. Freshw Biol [serial on the Internet]. 2013; 58(1):50-62. Available from: https://doi.org/10.1111/fwb.12037

Olden JD, Kennard MJ. Intercontinental comparison of fish life history strategies along a gradient of hydrologic variability. Am Fish Soc Symp. 2010; 73:83-107.

Olden JD, Poff NL, Bestgen KR. Life-history strategies predict fish invasions and extirpations in the Colorado river basin. Ecol
Monogr [serial on the Internet]. 2006; 76(1):25-40. Available from: https://doi.org/10.1890/05-0330

Paugy D. Reproductive strategies of fishes in a tropical temporary stream of the Upper Senegal basin: Baoule river in Mali. Aquat Living Resour [serial on the Internet]. 2002; 15(1):25-35. Available from: https://doi.org/10.1016/S09907440(01)01144-5

Poff NL, Allan JD, Bain MB, Karr JR, Prestegaard KL, Richter BD, Sparks RE, Stromberg JC. The natural flow regime, a paradigm for river conservation and restoration. Bioscience [serial on the Internet]. 1997; 47(11):769-84. Available from: https://www. jstor.org/stable/1313099

Pusey BJ, Arthington AH, Bird JR, Close PG. Reproduction in three species of rainbowfish (Melanotaeniidae) from rainforest streams in northern Queensland, Australia. Ecol Freshw Fish [serial on the Internet]. 2001; 10(2):75-87. Available from: https://doi.org/10.1034/j.1600-0633.2001.100202.x

Ramos LA, Konrad HG. Contribuição ao estudo da biologia reprodutiva de Rineloricaria microlepidogaster (Osteichthyes, Loricariidae) do rio dos Sinos, RS. Acta Biol Leopold. 1998; 20(2):299-307.

Ramos LA, Konrad HG. Biologia reprodutiva de Hemiancistrus sp. (Osteichthyes, loricariidae) do rio dos Sinos, RS. Bol Inst Pesca. 1999; 25:45-50.

Reis RE, Weber C, Malabarba LR. Review of the genus Hypostomus Lacépède, 1803 from southern Brazil, with descriptions of three new species (Pisces, Siluriformes, Loricariidae). Rev Suisse Zool. 1990; 97(3):729-66.

Reynalte-Tataje DA, Hermes-Silva PAS, Bialetzki A, ZaniboniFilho E. Locais de crescimento de larvas de peixes na região do Alto Rio Uruguai. In: Zaniboni-Filho E, Nuñer APO, editors. Reservatório de Itá: Estudos ambientais, desenvolvimento de tecnologias de cultivo e conservação da ictiofauna. Florianópolis: Ufsc; 2008. p.159-194.

Reynalte-Tataje DA, Zaniboni-Filho E, Bialetzki A, Agostinho AA. Temporal variability of fish larvae assemblages: influence of natural and anthropogenic disturbances. Neotrop Ichthyol [serial on the Internet]. 2012; 10(4):837-46. Available from: http://dx.doi.org/10.1590/S1679-62252012000400017

Roa R, Ernst B, Tapia F. Estimation of size at sexual maturity: an evaluation of analytical and resampling procedures. Fish Bull. 1999; 97(3):570-80.

Rutaisire J, Booth AJ. Reproductive biology of ningu, Labeo victorianus (Pisces: Cyprinidae) in the Kagera and Sio Rivers, Uganda. Environ Biol Fishes [serial on the Internet]. 2005; 73(2):153-62. Available from: https://doi.org/10.1007/s10641004-5564-8

Suzuki HI, Agostinho AA, Winemiller KO. Relationship between oocyte morphology and reproductive strategy in loricariid catfishes of the Paraná river, Brazil. J Fish Biol [serial on the Internet]. 2000; 57(3):791-807. Available from: https://doi. org/10.1111/j.1095-8649.2000.tb00275.x

Suzuki HI, Vazzoler AEAM, Marques EE, Perez-Lizama MA, Inada P. Reproductive ecology of the fish assemblages. In: Thomaz SM, Agostinho AA, Hahn NS, editors. The Upper Paraná River and its Floodplain: physical aspects, ecology and conservation. Leiden: Backhuys Publishers; 2004. p.271-291.

Tedesco P, Hugueny B. Life history strategies affect climate based spatial synchrony in population dynamics of West African freshwater fishes. Oikos [serial on the Internet]. 2006; 115(1):117-27. Available from: https://doi.org/10.1111/ j.2006.0030-1299.14847.x 
Tedesco PA, Hugueny B, Oberdorff T, Dürr HH, Mérigoux S, Mérona B. River hydrological seasonality influences life history strategies of tropical riverine fishes. Oecologia [serial on the Internet]. 2008; 156(3):691-702. Available from: https:// doi.org/10.1007/s00442-008-1021-2

Torres-Mejia M, Ramírez-Pinilla MP. Dry-season breeding of a characin in a tropical mountain river. Copeia. 2008; 2008(1):99104.

Vazzoler AEAM. Biologia da reprodução de peixes teleósteos: teoria e prática. Maringá: Eduem; 1996.

Verhoeven KJF, Simonsen KL, McIntyre LM. Implementing false discovery rate control: increasing your power. Oikos [serial on the Internet]. 2005; 108(3):643-47. Available from: https://doi. org/10.1111/j.0030-1299.2005.13727.x

Waite TA, Campbell LG. Controlling the false discovery rate and increasing statistical power in ecological studies. Ecoscience. 2006; 13(4):439-42.

Winemiller KO. Patterns of variation in life history among South American fishes in seasonal environments. Oecologia [serial on the Internet]. 1989; 81(2): 225-41. Available from: https:// doi.org/10.1007/BF00379810

Winemiller KO, Agostinho AA, Caramaschi EP. Fish ecology in tropical stream. In: Dudgeon D, editor. Tropical Stream Ecology. San Diego: Academic Press; 2008. p.107-146.

Winemiller KO, Rose KA. Patterns of life-history diversification in North American fishes: implications for population regulation. Can J Fish Aquat Sci [serial on the Internet]. 1992; 49(10): 2196-2218. Available from: https://doi.org/10.1139/f92-242

Zeug SC, Winemiller KO. Ecological correlates of fish reproductive activity in floodplain rivers: a life-history-based approach. Can J Fish Aquat Sci [serial on the Internet]. 2007; 64(10):1291301. Available from: https://doi.org/10.1139/f07-094

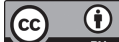

Submitted January 04, 2018 Accepted October 16, 2018 by Clarice Fialho 